can't you tell me the truth now it's done?

Just once, tell me

how you put me in that field

knowing he'd come,

that you made snow fall

everywhere to cover your tracks,

that the leaves die still

because you can't punish him

for confirming your suspicions:

not wanting you,

he took me instead.

Of course I ate those seeds.

Who wouldn't have

exchanged one hell for another?

\title{
In the Garden of Banana and Cocoanut Trees
}

Before the woman's hips

would come to sashay

to other rhythms,

before the man's hands

would grow still, leave

the hollowed-out wood body,

before she would take lovers

over her children,

before his mind would lose

itself to songs

of angels and demons,

before the gospel and herb,

there was my mother, cooking cornmeal porridge,

plantains and callaloo for later, 
my father's guitar notes, streaming in from the garden to hold her singing, his music, breathing, lifting leaves

that would collect and stir at his feet, my mother's clapping hands, bells jingling on her ankles.

\author{
Apple \\ Father, \\ watching you peel the fruit, \\ knife flat against flesh, \\ your fingers taut, white at the knuckles, \\ strips of skin flayed and falling \\ to the ground, \\ I think I love you \\ as Eve must have loved her father \\ when He turned her out \\ with the man who only knew \\ how to follow, \\ while $\mathrm{He}$ sat in the garden, \\ eating the white meat \\ with the serpent
}

